\title{
A rotina antes do paraíso: narrativas sobre a história de um destino turístico potiguar
}

\author{
Tiago Cantalice da Silva Trindade
}

\begin{abstract}
resumo $\mathrm{O}$ presente artigo propóe-se a realizar uma breve análise das alteraçóes no cotidiano da comunidade da Praia da Pipa-RN, que foram diretamente impulsionadas pelo advento do turismo - constituinte da paisagem local. Baseando-se nos dados adquiridos durante a pesquisa etnográfica, na qual os moradores mais antigos do distrito tiveram papel fundamental na construção e registro dessa história oral, buscou-se questionar a representação prosaica que se faz dos destinos turísticos como detentores de uma pureza, autenticidade e ingenuidade, que são ameaçadas pelo intenso fluxo desses forasteiros. Assim, o trabalho tenta evidenciar o quanto o turismo pode transformar as redes de sociabilidade locais, ao mesmo tempo em que a comunidade receptora cria mecanismos de reformulaçóes simbólicas diante dessas mesmas mudanças, ou seja, mesmo quando são induzidas por fatores externos, elas são conduzidas de modo nativo, o que fica claro através da observaçáo dos câmbios ocorridos nas relaçôes de gênero.
\end{abstract}

palavras-chaves História Oral. Turismo. Relaçóes e Representaçóes de Gênero. Trocas Culturais. Agência.

\section{Introdução}

Este artigo é composto por parte dos registros e análises que resultaram do estudo etnográfico realizado na Praia de Pipa, no litoral potiguar - foco de grande movimentação turística -, que serviram de base para o desenvolvimento de meu trabalho de dissertação, cujo objetivo era buscar compreender as interaçóes afetivo-sexuais entre mulheres estrangeiras e homens nativos/locais. Contudo, antes de refletir sobre o foco central da pesquisa, fazia-se necessário a tentativa de remontar a história da praia, partindo das trajetórias de vida de alguns/mas de seus/ suas mais antigos/as moradores/as, explorando como eram o cotidiano, as relaçóes interpessoais e a organização social na comunidade de Pipa no período anterior ao advento do turismo, para logo em seguida apresentar sua atual conjuntura, destacando as mudanças vindas juntamente com as levas de forasteiros que se espraiam por todas as partes do distrito e como a comunidade local foi adaptando-se e também tomando parte nessas transformaçóes. Assim, torna-se mais fácil visualizar, a posteriori, as manipulaçōes e reformulaçóes simbólicas realizadas pela comunidade receptora do destino turístico de Pipa, que objetiva tirar proveito da chegada dessa atividade, com destaque aqui para a manufatura das representaçóes locais de gênero empreendida por alguns homens autóctones e adventícios. Vale frisar que serão exatamente essas relaçóes e representaçóes de gênero que desempenharão a função de eixo norteador e termômetro dos câmbios sociais que se deram em Pipa.

\section{Praia da Pipa: uma história feita de histórias}

A Praia da Pipa é um dos distritos do município de Tibau do Sul e fica localizada a cerca de 
I74 | Tiago Cantalice da Silva Trindade

$90 \mathrm{~km}$ ao sul de Natal, capital do Rio Grande Norte. Desde a segunda metade da década de 1990, Pipa vem se tornando um grande centro de atração turística do estado, tão divulgada e visitada quanto a capital potiguar.

Não há dados disponíveis e precisos no site da Secretaria Estadual de Turismo (SETUR-RN) sobre Pipa, apenas a informaçáo de que o distrito está entre os cinco destinos potiguares mais frequentados, sendo que o fluxo total de turistas para o estado, entre brasileiros e estrangeiros, em 2006 (dados mais recentes), foi de 2.186 .880 visitantes. Desse total, pouco mais de $30 \%$ foram de estrangeiros, vindos majoritariamente de Portugal (6,17\%), Espanha $(5,83 \%)$, Itália $(4,83 \%)$, Holanda (2,81\%), Inglaterra (1,47\%), Noruega (1,47\%), Argentina $(1,39 \%)$ e França $(1,22 \%)^{1}$. Tratando-se de turismo doméstico, os principais estados a emitir turistas para o Rio Grande do Norte são Pernambuco (13,72\%), São Paulo (13,08\%), Paraíba (9,03\%), Ceará (8,03\%), Rio de Janeiro $(7,89 \%)$, Distrito Federal $(3,00 \%)$, Bahia $(2,67 \%)$, Minas Gerais $(2,25)$ e Rio Grande do Sul $(1,22 \%)^{2}$.

De maneira geral, estes são também os estados e países de origem da maioria dos turistas que visitam a Praia da Pipa, só que, ao contrário do que ocorre com o resto do estado, pelo que se pôde observar, a maioria deles parece ser formada por estrangeiros ${ }^{3}$. Mas duas questóes se impóem: como essa praia tornou-se um grande pólo turístico internacional? Como era a vida em Pipa antes da chegada do turismo?

Dados da contagem do IBGE (Instituto Brasileiro de Geografia e Estatística), feita em $2007^{4}$, nos informam que a populaçáo do município de Tibau do Sul é de 10.959 habitantes $^{5}$. Esse nome, de origem indígena, significa "entre duas águas", já que o povoado fica entre a Lagoa Guaraíras e o Oceano Atlântico. A regiâo já foi habitada por indígenas, "descoberta" pelos portugueses, invadida por piratas france- ses ávidos pela extração de Pau-Brasil e, posteriormente, ocupada por holandeses ${ }^{6}$. De base agrícola, o local primeiro se chamava Aldeia de São João Batista de Guaraíras. Em 1911 adquiriu a condição de distrito de Goianinha, já sob a nomenclatura de Tibau. Em 1953, foi elevado à condição de Vila; dez anos depois, Aldeia de São João Batista de Guaraíras foi desmembrada do município de Goianinha, e durante sua emancipaçáo acrescentou-se a locução adverbial "do Sul" ao seu nome original para se diferenciar de uma localidade homônima no litoral norte do estado.

Nessa época, por volta da década de 1950, Pipa não passava de uma vila de pescadores, desprovida de quaisquer intervenções e benefícios governamentais. Não havia água encanada, tratamento de esgoto, rede pública de energia, atendimento público de saúde, rede de ensino, muito menos estradas de acesso. $\mathrm{O}$ meio de transporte mais usado eram os carros de boi e os cavalos.

Para podermos vislumbrar melhor a dinâmica social desta praia, quando ela ainda não havia sido descoberta pelos turistas, recorremos à memória de alguns de seus/suas antigos/as moradores/as para tentar delinear a história do povoado da Pipa, não apenas pela ausência quase total de registros bibliográficos sobre seus primórdios, mas, sobretudo, como método etnográfico, numa legítima tentativa de captar de que maneira esses discursos vão sendo revelados. Busca-se explicitar quais os marcos significados na pragmática dessa população como históricos, o que é digno de ser rememorado, como os mitos de origem vão sendo construídos nessas narrativas de vida, na história oral contada por aqueles/as que viveram todo o processo de transformaçáo do vilarejo da Pipa em destino turístico e que é transmitida de geração a geração.

A primeira pessoa com quem conversamos durante o trabalho de campo com esse intuito foi D. Domitila, professora aposentada que 
vive em Pipa desde que nasceu, há 83 anos eremete-se às histórias que eram a ela contadas por seus pais e avós para remontar à história do lugar. Antes da chegada dos seus familiares na regiáo existiam apenas posseiros. Ela informa que sua família sempre morou em Pipa e que na verdade foi uma das primeiras a se instalar pela localidade. D. Domitila revela que a praia recebeu o nome de Pipa devido a uma pedra, tomada como ponto de referência pelos pescadores, que a achavam semelhante a um barril de pipa, daqueles em que se armazena vinho7.

Toda vida, [minha família] sempre foi daqui. Quer dizer, o meu avô, meu bisavô, meu avô não, era meu bisavô, ele era da Itália, ele veio da Itália, disse que pra lá... E não veio só ele não, na expedição que ele veio, veio muita gente pra cá, porque disse que lá tinha uma lei, que eles não... o... não sei se essa época era governo ou se era rei, não sei o que era... Eu sei que disse que não aceitaram lá o que ele queria, né? Aí fugiu um povo, como hoje em dia o povo num foge né? Aí, fugiram nessas barcaças, que disse que era umas barcaça, que antigamente tinha umas vela assim que cruzava, disseram que o povo saiu tudo naquelas barcaças ['É Nau!', completa Dani, sua neta.] e chegaram aqui. Quando chegaram aqui no Brasil, aí muita gente se assituou por aqui, de Goianinha pra cá, muita gente se assituou onde esse meu bisavô se assituou aqui. Aí, diz que ele se agradou daqui e o que eles faziam quando chegaram aqui no Brasil era mascatear, era comprar o tecido, comprava uns baú grande e comprava um animal e andavam vendendo aqueles tecidos. Chamavam mascate, né? Andando, mascateando. Entáo era isso o que eles faziam. Então meu avô andando por aqui, meu bisavô andando disse que admirou-se muito disso aqui e entáo comprou um terreno bom aqui, dois terrenos grandes e que pretendia morar aqui, viver aqui, casar, como de fato fez tudo isso (D. Domitila, 83, professora aposentada).
Essa versão sobre a história do início do povoado é reproduzida por sua filha, D. Palmira, 47 anos, também nascida e criada em Pipa. Ao mito de origem narrado por sua máe, ela acrescenta que esses primeiros moradores, que vinham da Itália, traziam consigo vários baús repletos de ouro, que foram enterrados por medo de que fossem roubados.

Olhe, um dos primeiros moradores diz que foi os meus bisavós. Meus avós, bisavós, né? Contava minha vó, isso aí já é uma coisa que eu lembro que ela me contava, que eles vieram embarcados. Era como se fosse uma história de que tinham fugido, que eles eram italianos, né? E vinham fugidos, né? Que é contrabando, né? Então, eles se ancoraram aqui e fizeram... Aí minha mãe sempre conta assim, que diz que minha vó, minha vó não, minha bisavó, diz que esses morro aqui, que isso aqui era tudo terra. [...] Aí, ela disse que foram os primeiros. Era o povo de minha vó que era dos Castelo, nera? Que eles chamavam de Siliveira, era Silveira, mas chamavam Siliveira, tá entendendo? Aí era o velho Castelo, Castelo Siliveira e diz que trazia, minha vó contava, meu bisavô trazia, quando ele vinha de contrabando, trazia... antigamente baú, era cuia de quarto, que era de madeira, cuia de quarto, essas coisas... disse que ele trazia assim, o barco cheio, só de ouro e media. Aí pra ninguém num pegar, ele enterrava. [Quem fazia isso?] Meu bisavô. Enterrou muita... Eu digo até hoje que aquele nojento devia ter deixado pra gente... [risos] (D. Palmira, 47 anos, proprietária e administradora de um camping).

A chegada de italianos fugidos por meio de naus, que aportaram em Pipa, trazendo consigo várias botijas de ouro, configura-se em um mito de origem, que nega sua ascendência portuguesa e inaugura um outro descobrimento, uma colonização distinta do resto da região, afinal esses indivíduos haviam se deslocado a 
fim de encontrar um lugar para se estabelecer e povoar, não meramente explorar, como evidencia a fala de D. Domitila. Está aí presente também a representação da ousadia e da bravura de um povo que desafiou autoridades, desbravou mares e se instalou numa terra inóspita, ademais sua astúcia e sagacidade em esconder seus tesouros para não serem fáceis alvos de saqueadores ${ }^{8}$.

Sabe-se, no entanto, que Pipa manteve-se praticamente isolada do restante do estado até o início da década de 1970. Antes disso, o local se limitava a duas ruas e algumas poucas famílias. As pessoas viviam da pesca e da agricultura, à base principalmente de mandioca para produção de farinha. Eram esses os dois produtos comercializados pelos moradores de Pipa com outros povoados da regiáo do entorno. Mas, de acordo com os interlocutores, a pobreza era predominante, afetava a todos, faltava de tudo e nem sempre havia compradores.

Eu alcancei aqui com muito pouca gente. Era... a Pipa era muito pequena pra hoje em dia, era pequena demais. Tinha poucas famílias, alcancei muita gente que já morreu, que era... Essa rua, que a gente mora, essa rua de baixo, que chama Rua de Baixo, né? Era fácil de contar as casas que tinha e a Rua de Cima era também do mesmo jeito. Era só essas duas ruas, pra canto nenhum mais a gente saía. Só tinha essas duas ruas. [E o pessoal vivia mais de quê?] De pesca, o homem que dava pra pescar era de pescaria, num sabe? E quem dava para a agricultura, era agricultor. Às vezes, quem era agricultor também era pescador, fazia as duas coisas. E aqui o povo vivia disso, não tinha... $\mathrm{O}$ pessoal aqui não tinha nem do que viver, era uma coisa... Sempre havia muito peixe, havia muito peixe. Farinha, quando eu era menina ainda, aí tinha farinhada aqui, que o povo botava muito roçado, muita farinhada nas casas de farinha. [Tinha muita casa de farinha?] Tinha umas cinco casa de fari- nha, tudo trabalhava. E todo mundo trabalhava de agricultura, quando era no tempo da, da... De outubro em diante aí começava as farinhada e terminava assim de fevereiro, março. E pescaria era durante o verão todinho, aí o povo pescava, havia muito peixe. Agora, o preço do peixe era quase nada, num sabe? Era bem baratinho. [Vendia pra outras cidades?] Vendia, às vezes aparecia gente assim que vinha do sertáo, desse meio de mundo, comprar peixe aqui e às vezes não vinha. $\mathrm{O}$ meu avô possuía curral de peixe? disse que quando era no tempo de safra de peixe, que dava no curral, dava muito peixe, ele ficava com o peixe todo aí sem ter quem comprasse, porque o povo num vinha comprar, era muito longe e também não havia transporte, só era a cavalo que o povo vinha aqui. A pé e a cavalo. [A estrada ia até onde? Ia até Goianinha?] A estrada ia até Goianinha, mas não prestava, era só de areia, num sabe? Areia, os matos, não dava pra passar um carro (D. Domitila).

Essas falas, aqui trazidas, são relevantes, pois nos ajudam a compreender a amplitude das transformaçóes pelas quais a Praia da Pipa passou após o advento da atividade turística. Dessa forma, conversei ainda com Seu Madola, um ex-agricultor, que mora neste pedaço de mundo desde que nasceu, há 70 anos, e que também presenciou todas essas mudanças. Esse senhor de cabelos brancos bem finos, dentes falsos, mas de sorriso verdadeiro, anda com a ajuda de uma bengala. Quando entramos em sua casa, a convite de uma de suas filhas, após ter me apresentado, sentamos num banco de madeira comprido, de tom cru. Lá, ele me contou as lembranças de um tempo em que Pipa era esquecida e quase ninguém sabia localizá-la no mapa:

Rapaz, a Pipa antigamente era um... uma sombrinha. E as casa era tudo de taipa, coberta de palha de coqueiro, num é? Só quem possuía 
uma casa, a casa coberta de telha era aquele melhorzinho, aquele melhor que nem Manuel do Hemetério, o véio Chico Castelo, que era o pai de D. Domitila, Antônio Pequeno e algumas pessoas, mas as outras era tudo casasinha comum, casasinha de, de... [Mas esses outros que tinham uma melhor condição trabalhava com a mesma coisa?] É, só na roça e pescaria. [Todo mundo aqui trabalhava em pescaria e roça.] Pescaria, a maior parte aqui foi uma praia que transportava peixe pra fora, farinha pra fora, aqui se achava cinco casa de farinha. Cinco casa de farinha. [E essas coisas vendia pra onde? Pra Natal?] O peixe, o matuto vinha, toda semana vinha apanhar, vinha comprar pra levar pra Santo Antônio, Nova Cruz, por aquelas quebrada de acolá tudinho, né? Era que nem farinha. [Era pouca gente que morava por aqui?] Pequeno. Só tinha mesmo moradia na rua de baixo, ali hoje onde é a praia, aquilo ali era uma rua, onde é aquelas barracas. A igreja era em frente àquela barraca que tem de, do menino lá, a derradeira que tem. Ali era uma igreja, a igreja. [Então essa aqui é nova?] É nova. Essa aqui tá com cinquenta e tantos anos de construída. A igreja lá, aonde tem aquelas barraca, aquilo ali era uma terra preta, tinha um pé de fruta-pão, um pé de fruta-pão bem na porta. Os bois de rede, você conhece Boi de Rede? [A dança? Boi de Reis?] Boi de Rede, que tem Boi Calema e tem... esse é Boi de Rede. Essa era a diversão que tinha antigamente. [Mas era do pessoal adulto ou das crianças?] De toda nação, toda a comunidade. Era Boi de Rede, era cantor de viola, era pastoril e era aquele Zambề $\hat{e}^{\bigotimes}$, aquele que bate aqui ó [entre as pernas] [Que ainda toca em Tibau?] Cabeceira [distrito de Tibau do Sul]. Aquele que bate aqui. E pastoril, Drama. [Como é que é o Drama?] O Drama é, é... cai que nem uma... como é que apresenta... [Um teatro?] Um teatro. É que nem um teatro (Seu Madola, 70 anos, ex-agricultor e tirador de coco).
Em suma, pelo que podemos ver nesses relatos, Pipa se resumia a muita terra e pouca gente. As áreas mais próximas da praia tinham cada uma seu dono, mas as áreas de cultivo, que ficavam na região mais alta e afastada, eram terras comuns, como diz Seu Madola, era terreno solto, mas quando alguém começava a tratar da área para cultivar alguma coisa, ninguém mexia. Depois de tirada a safra, a terra era abandonada, formando as capoeiras.

As roças, os plantios de roça era aqui pra dentro, na mata. Aquilo ali que brocava o mato, começava no mês de Santana [Julho], cortar mato né? Santana, agosto, setembro, quando era em outubro se ia plantar. Quando o inverno era mais favorável, nascia toda, mas quando não era perdia uma parte, outra, mas outra se livrava. É outubro, novembro, dezembro, janeiro, até fevereiro se plantava roça aqui. [Mas essas roça tinha dono ou era terra de ninguém?] Todos nós era produtor, cada uma família botava uma parte. [Mas o terreno não tinha dono não? Era cercado?] Não, era bem mesmo da comunidade (Seu Madola).

O ritmo de vida em Pipa era radicalmente diferente. Sem energia elétrica, o sol é que ditava a hora de dormir e acordar. Com os seus primeiros raios ou com a cantoria dos galos ainda de madrugada, as pessoas se levantavam para mais um dia de labuta. O candeeiro, ao contrário, trabalhava poucas horas, pois bastava o sol descer no horizonte e se deitar lá para as bandas da Lagoa Guaraíras, que as pessoas se aprontavam para dormir.

Pipa também contava com uma divisão do trabalho pouco complexa, baseada no gênero, na idade e nas relaçôes de parentesco. Todos sabiam qual era o trabalho do homem e a função da mulher. Ao homem cabia realizar a pesca, construir e consertar os barcos, preparar os terrenos para receber as sementes, arrancar as 
mandiocas, moê-las e cozinhar a farinha, assim como deslocar-se até Goianinha para vender peixe e farinha na feira. As mulheres, além do trabalho doméstico, estavam incumbidas das tarefas de retirar água das cacimbas - esses poços artesianos só existiam em alguns pontos da Rua de Baixo -, elas também contribuíam na agricultura e ajudavam na fabricação da farinha, raspando a mandioca, cevando a moenda e limpando a goma. $O$ processo da produçáo da farinha é detalhado por D. Domitila:

Os homens era pra arrancar a mandioca, botar pra casa de farinha e vinha em animal e as mulheres raspar, né, a mandioca, cevar, aí era uma roda, dois homens, um de um lado, outro de outro, moendo. E a mulher cevando, aí caía aquela massa, aí daquela massa que caía, tinha uma prensa, aí botava uns negoço como umas tábuas, assim, assim, assim [uma de um lado da outra], aí botava aquilo ali com uns panos de carnaúba, tirava as folhas de carnaúba e botava aquilo naquela massa em cima, aí quando acabava tinha uma prancha desse tamanho assim, botava em cima, tinha um fuso assim e tinha um pau que botava naquele fuso que era furado e aí rodava, aquilo rodava, rodava e ia imprensando, ia imprensando e aquela aguinha ia saindo da massa, até ela enxugar, ficava bem enxutinha. Aí tirava daquela prensa, botava no poço, as mulher penerava, aí ia pro forno, né? Secar aquela massa, aí era a farinha.

Pelo que esses relatos deixam-nos entrever, em Pipa, as atividades produtivas não se limitavam à pesca. Apesar de sua origem ser atrelada à ideia de uma comunidade de pescadores, havia também a produção agrícola e a fabricação de farinha, que, juntamente com o peixe, era um item comercializado nas redondezas. Para Ellen Woortmann (2007), que pesquisou algumas comunidades litorâneas da costa potiguar, o realce dado à atividade de pesca deve-se ao fato de que a maioria dos estudos sobre tais comunidades privilegia o ponto de vista do homem, ou seja, do pescador. Assim, segundo ela, a agricultura, pensada como uma atividade feminina, termina por ser subsumida por esse ponto de vista. Woortmann ainda propóe a ideia de que ao espaço natural desses locais sobrepóem-se espaços sociais, definidos com base no gênero. Dessa forma, o mar é percebido como domínio do homem e a terra, como da mulher, com alguns pontos de trabalho conjunto, a exemplo da praia.

Entretanto, pelo que se pôde ver, em Pipa, esse esquema dicotômico não tem contornos tão bem definidos. Apesar de o mar ser realmente um espaço masculino, como afirma D. Palmira, a terra não era um domínio totalmente feminino. As atividades ligadas à agricultura eram desempenhadas conjuntamente, tanto por mulheres quanto por homens, o que se estendia também à produção de farinha. Essa bipolarização espacial, portanto, não é condizente, nesses moldes, com a realidade aqui estudada $^{11}$. O domínio da mulher talvez estivesse mais atrelado ao espaço da casa em si.

As crianças, por sua vez, brincavam com a imaginação e a criatividade. Numa terra com poucos habitantes, carente de uma série de recursos, os brinquedos tinham de ser inventados ou, então, os objetos tinham de ganhar novos significados. Assim, faziam-se cata-ventos de palhas de coqueiro, as latas viravam carros, as mangas tornavam-se vacas e bezerros, as espigas de milho se transformavam em bonecas. Logicamente se brincava na praia, brincava-se de roda, cabra-cega, mancha, entre outras brincadeiras.

Os adultos divertiam-se através dos folguedos, do Boi de Rede, do Coco de Zambê, das cantorias de viola, do Pastoril e do Drama ${ }^{12}$, além das festas religiosas, com destaque para as comemorações do padroeiro, São Sebastião. Aliás, a religiosidade estava sempre muito pre- 
sente na vida das pessoas. O catolicismo era sua única expressão e as festas de santo movimentavam todo o vilarejo. D. Domitila, mostrando o quanto a dedicação à religiáo era expressiva, recorda que para construir a igreja atual todas as pessoas ajudaram, carregando pedras para erguer seu alicerce e suas paredes.

As orientaçóes religiosas eram responsáveis também pela vigília que os pais faziam sobre os namoros. $\mathrm{O}$ controle sobre esses relacionamentos era extremamente rígido. As famílias temiam que suas filhas fossem desonradas e, assim, comprometessem suas chances de selar uma aliança duradoura e abençoada pelo matrimônio. Esse controle, além dos olhares vigilantes, incluía ameaças verbais e físicas. Os relatos colhidos comprovam essas informaçôes e acrescentam que a maioria dos casamentos dava-se entre pessoas da própria comunidade, apesar de algumas vezes serem estabelecidos matrimônios com pessoas de outros lugarejos. Não obstante, apesar do tradicionalismo que envolvia os relacionamentos amorosos, não havia, segundo os interlocutores, o costume de ocorrerem casamentos prescritos, comuns em outras regióes, em que as filhas, às vezes logo após o nascimento, eram prometidas a serem casadas com determinados rapazes, visando estabelecer e/ou estreitar relaçóes entre duas famílias distintas. Todavia, os interditos eram numerosos.

Ah, meu filho. Os namoros de antigamente, meu filho, misericórdia, não pegava nem na mão um do outro. Eu me casei em [19]48... Foi! Quarenta e oito eu me casei, em junho de 48, aí, nessa época, em 48, já era muita coisa avançada, mas eu não tinha o direito, que lá em casa tinha uma casa de farinha, assim perto da casa, já parede e meia com a casa. A casa de farinha assim pelo sul, a casa assim [na frente]. Eu não tinha o direito de ir com meu namorado nem pra casa de farinha, que, às vezes, a gente queria ir ajeitar qualquer coisa pra comprar, porque aqui as pes- soas não esperava por ninguém, né? As minhas coisas era eu quem fazia. Aí lá, ele [- seu pai -] dizia que se eu tivesse o atrevimento de ir falar com ele [- seu namorado -], me dava uns bofete e era assim. Ninguém tinha o direito de nem beijar, de nem de andar pra canto nenhum, era proibido tudo. Sabe como é tudo? O negoço de casar, chegava o dia: 'A senhora quer me dar sua filha em casamento?' 'Dô!', se tava tudo certo, 'Dô!', aí ia ela pra esperar pelo casamento pra poder você ter direito... [risadas] [Mas num tinha aquela história de ficar prometendo a filha, mesmo antes de nascer, pra um outro?] Não, não, tinha não. Quando eu nasci, não alcancei... desde que nasci não. Mas o negoço dos namoro era difícil, ninguém tinha liberdade não (D. Domitila).

Os namoro, antigamente, pra o rapaz dar um beijo numa moça era preciso ser roubado, quando a véia, quando o pai mais a máe cochilava, o camarada tava em riba dela dando beijo. Hoje não, hoje até os padre diz: 'Vai beijar não?' [risos] [Aqui tinha a tradição de prometer a filha ao filho de um amigo? Do casamento ser arranjado?] Não, não. O rapaz quando dava de namorar com uma moça, aí tinha uns que passava dois, três anos, quatro, aí quando, e às vezes, porque você sabia, a lenha perto do fogo, não tem como... Aí quando dava fé o cabra mexia com uma, aí quando aparecia a história, aí o pai mandava chamar seu Fulano, aí casava, né? Quando num queria, vai pra justiça e a justiça obrigava. Mas hoje não, hoje ele casa se quiser. [... Eu sei que o senhor é daqui, mas sua mulher é daqui também?] É. [Era geralmente assim, duas pessoas nascidas aqui?] É, mas tinha gente que chegava, namorava com os de fora. Tanto as daqui casava com os de fora, como as de fora casava com os daqui também (Seu Madola).

Os relatos acima mostram como os relacionamentos amorosos eram marcados por uma série de prescriçôes, que pretendiam minimizar 
os perigos previsíveis que a "lenha perto do fogo" podia trazer à honra da família, haja vista que tais relaçóes, aos olhos dos pais, pareciam predeterminar as açóes (Sahlins, 2003) e algumas delas geralmente levavam ao descrédito social e moral dos sujeitos transgressores. Dessa forma, qualquer espécie de contato mais íntimo, como um beijo, deveria ser efetuado com bastante atenção e cautela, caso contrário, os mecanismos sociais (formais e informais) de controle dos corpos e dos desejos seriam prontamente acionados.

Outro ponto a se destacar é que as interaçốes com pessoas de fora não se limitavam ao comércio. Esses sujeitos tomavam parte também no mercado matrimonial pipense, como mostra a fala de Seu Madola. "Os (as) de fora" não eram pipenses, mas seguramente também não provinham de áreas muito distantes do atual distrito. Eram pessoas, conforme diz D. Palmira, oriundas dos municípios da redondeza, como seu falecido pai, que era de Barra de Cunhaú, praia vizinha.

Ao trazer esses dados, náo se quer negar a possibilidade de agência desses indivíduos, deseja-se apenas frisar que numa sociedade um tanto quanto isolada, em contato com outros grupos sociais orientados por valores e instituiçôes semelhantes, tendo apenas a religião católica, em sua vertente mais popular, o parentesco e a divisáo sexual do trabalho como organizadores sociais, o campo de ação dos indivíduos tornava-se bastante limitado, cerrados entre atos prescritivos e interditos. Isso fica evidente nas falas, explicitadas acima, sobre a conformaçáo dos relacionamentos amorosos, que exigia o respeito aos ideais de masculinidade e feminilidade estabelecidos coletivamente.

Contudo, as diferenças entre a Pipa de hoje e a de sessenta ou cinquenta anos atrás não se limitam ao modo de vida. A geografia do local também era muito distinta. Além das grandes faixas de terra sem nenhuma habitação, da ve- getação densa e abundante, o mar era bem mais recuado. Onde atualmente existe uma fileira de barracas (quiosques) rentes ao quebra-mar, na praia principal, existia uma rua de areia preta, algumas casas e, antes do mar, um coqueiral. Seu Madola diz que para se ter uma noção do quanto o mar era afastado, havia um pátio de vaquejada na frente da Rua de Baixo.

A roça e as capoeiras ficavam em oposição às praias e junto com elas compunham os principais referenciais da regiáo. Sua orla, de acordo com D. Palmira e Seu Madola, seguia a seguinte divisão, a partir do seu limite com a sede do município de Tibau do Sul: Praia de Cacimbinhas (o nome refere-se às grandes e inúmeras depressóes que se formam no solo marinho), Praia do Madeirinho, Praia do Madeiro, Praia do Curral (em referência a um curral de pesca que ainda se encontra no local, porém abandonado) ou Praia do Canto, Ponta do Morcego, Praia do Porto, Praia da Pipa (Praia da Frente ou Praia Principal), Praia dos Afogados (um alerta para o mar revolto), Praia do Moleque, Praia da Cancela, Praia das Minas (em referência às histórias das botijas enterradas com ouro) e Praia de Pedra D'água, no limite com o distrito de Sibaúma. Algumas dessas denominaçôes foram alteradas com a chegada do turismo, como conta Seu Madola:

Olhe, a Praia dos Golfinhos foi montado depois que o pessoal [os turistas] chegou. A praia ali do Amor foi depois também que o pessoal chegaro. Agora, os veranistas de Goianinha, quando vinham veranear foi que botaram o nome daí, do alto, do Morro dos Amores, era onde eles paqueravam né? [Mas é mais pra cá, né?] É aí, esse morro aí, era esse morro né? Eles subiam e paqueravam ali em cima, fazer amor por lá por cima, por isso que botaram o nome do Morro do Amor. Agora, depois foi que passaram pra... depois que pôs a chegar esse povo, a Praia do Amor. [Agora, a Praia do Amor sempre teve esse 
nome ou era outro nome ali?] Não. Foi agora desses tempos pra cá. Era os Afogados. [E os Golfinhos, tinha outro nome?] Os golfinhos chamava a Praia do Madeira, Madeirinha e o Canto. O Canto é esse aqui, logo esse aqui [a primeira ponta], o Madeira é aquele que tem o hotel em cima e Madeirinha é aquela outra ponta que tem pra pegar Cacimbinhas.

A notória mudança nos modos de vida, nos referenciais da praia e na estrutura da cultural local, que se deu com maior intensidade nos últimos 15 anos, foi induzida por um elemento externo, o turismo, mas, como veremos, e parafraseando Marshall Sahlins (2003), foi conduzida e orquestrada de modo nativo.

\section{O Paraíso são os Outros! - da construção turística de um destino}

Na década de 1960, antes mesmo da abertura da estrada atual, quando o distrito não possuía energia elétrica nem água encanada, os primeiros visitantes começaram a aparecer, vindos principalmente do município de Goianinha, a $27 \mathrm{~km}$. A pequena distância tornava-se grande quando levamos em consideração as condiçóes da via de acesso e os meios de transporte utilizados.

A estrada ia até Goianinha, mas não prestava, era só de areia, num sabe? Areia, os matos, não dava pra passar um carro. Aí quando o pessoal de Goianinha começaram a... que deram com essa praia aqui, que começaram a veronear, que chamavam veronista, os que vinha de Goianinha, Natal, né? Aí chamavam de veronista, não era turista naquela época, era veronista. Aí eles vinha, passava o verão aqui, o mês de janeiro, fevereiro, aí vinha em carro de boi. Carro de boi, não sei se você conhece carro de boi, né? Aí vinha no carro de boi e quem podia, os mais velhos, vinha naquilo, os mais novo vinha a cava- lo. Era assim, não tinha estrada, não tinha nada (D. Domitila).

O fluxo desses visitantes era baixo e se restringia ao período do verão, que coincide com o das férias escolares. Dessa forma, uma vez ao ano já era esperado que alguns veranistas chegassem à praia. Contudo, a partir da segunda metade da década de 1970, surfistas começaram a aparecer na regiāo, seduzidos pelas ondas, que até hoje atraem boa parte dos visitantes. Os interlocutores os consideram responsáveis pela disseminação do nome da praia pelo estado e pelo país, atribuindo-lhes o posto de descobridores da Pipa.

Começou vir, olhe, as primeiras pessoas que chegaram aqui foram... quem descobriu mais isso aqui foram os surfista, que vinham pra cá e aí saíam espalhando, né, que a praia era muito boa, tudo mais. Aí haja vir gente fotografar, levava pra lá, saía revista, saía atrás e aí foi continuando. [E eles ficavam onde?] Ficava aqui... quando era esses surfista, ficava na casa de Deda, do finado Deda, que era um pequenininho que tinha aqui, que fazia comida pra eles, ficava na casa de Marina, ficava na casa de Eunice e pra eles dormirem, pra você vê, pra eles dormirem, eles amarrava as rede nos coqueiro, de um coqueiro pra outro. Cê acha que eles no verão, eles procurava o carro? Não, dormia assim, ao relento mermo, dormia dentro dos carro. Aqui podia dormir com o carro aberto, num tinha quem bulisse em nada, neste tempo não tinha quem bulisse [...] (D. Domitila).

[E depois, dos veranistas de Goianinha, quem foram os primeiros pra vir pra cá visitar?] Os surfistas. Na década de setenta, de setenta e sete pra setenta e oito apareceu os primeiros surfistas por aqui. Abacate foi um dos primeiros surfistas, era Abacate, acho que era Zé Ramalho, o nome. Edivaldo veio mas eu num conhecia Edivaldo 
não... Mas sei que foi esse Abacate, que até hoje eu sei que o Abacateiro ainda tá lá, né? Que foi em homenagem a ele. Mas Edivaldo foi... [Aí plantaram um abacateiro em homenagem a ele?] Não, o Abacateiro é o nome do ponto [de surf.] [...] Aí Abacate começou a namorar com a filha de Manoel do algodão, com Marleide. Aí ela começou a namorar com esse surfista, aí disseram que engravidou, não sei [...] Aí Deda, que era aleijadinho assim, era quem acolhia os surfista, que era quem cozinhava pra eles, que fazia tudo pra eles. Aí eles ficavam na casa de Deda. [Acampados?] Acampados, náo. Ficavam na casa dele mesmo. [...] Aí ele é quem cozinhava pra esses surfistas, todo mundo que vinha procurava logo Deda... [Entáo era mais homens que vinha pra cá.] Era só homem, só homem... E era assim, mais em Jipe, nesses carros assim (D. Palmira).

Pouco tempo depois da chegada desses precursores ádvenas, levas de outros surfistas e hippies, vindos de Natal, Fortaleza, João Pessoa e Recife, começaram a aportar em Pipa, encantados com as suas belezas naturais e rusticidade de seu povoado.

Depois de algumas melhorias na infraestrutura de base, como a instalação de uma rede de abastecimento de água, no início dos anos de 1980, a distribuição pública de energia e a construção de uma via asfaltada, no início da década seguinte, um número cada vez maior de pessoas deslocou-se para lá, vindas de cada vez mais longe, muitas delas da regiấo Sudeste do país. Foi após a construção da estrada entre Goianinha e Pipa que também apareceram os primeiros turistas estrangeiros. Daí em diante, surgiram as primeiras pousadas e hotéis, que, em pouco tempo, começaram a dominar a paisagem.

Os gringos? Acho que na década de [19]80... Acho que depois da estrada, visse? Em 89 mais ou menos, entre 88 e 89 , que começou a vir os gringos... Aí começaram a comprar aqui em dólar, né? As coisas. [E era por agência que eles vinham?] Que eu saiba não, visse? Eles vinham sozinhos... E aí quando vinha, ficava embelezado com a natureza e eles queriam ficar, aí, inventavam de comprar... Aí compravam e como o dólar na época era muito mais alto... Aí eles compravam aqui barato, barato demais ficava um terreno aqui... compraram aqui um bocado de coisa com dólar (D. Palmira).

Os gringo? Rapaz, os gringo chegaro aí de quinze anos pra atrás. Um pouco mais ou menos, né? Quer dizer que algum que vinha, só vinha só e voltava logo. Mas esses que tão assituado aí, que vieram, assim, de botar comércio, pra melhorar mais a situaçấo, foi de quinze anos atrás pra cá, num foi? [Eles viajavam geralmente sozinhos ou já vinham em grupo?] Não, eles sempre que viajavam... naquele tempo era mais calmo do que hoje. Vinham sozinhos. [Nesse tempo já existia pousada?] Já, tinha pousada, a primeira pousada, o primeiro hotel que foi construído aqui na praia da Pipa foi aquele dali que chamam, como é? Da Madeirinha. [O Village?] O Village e aí aquele da ladeira, que desce pra ladeira do Amor. [O Sombra e Água Fresca?] Que foi de Elôncio. [É o Sombra e Água Fresca?] Não, aquele que tem ali embaixo. O Hotel da Pipa. Foi o primeiro que funcionou aqui (Seu Madola).

Nesse período, chegar em Pipa ainda era muito atribulado; por isso, quem quisesse conhecer a praia tinha que fazê-lo por conta própria, e era assim que esses viajantes realizavam suas excursóes, de forma independente, sem a mediação de agências de viagens. Muitos desses brasileiros e gringos $^{13}$ ficaram estonteados com Pipa e adotaram-na como local de residência. Os estrangeiros tinham mais facilidade de comprar terrenos e imóveis devido à força de suas moedas. As terras que antes ficavam ao relento e que pouco ou nada valiam como mo- 
eda, do dia para a noite, começaram a adquirir mais e mais importância frente aos anseios dos ávidos empreendedores do turismo. A terra, antes subestimada, por existir em abundância, conquistou um valor de troca nunca imaginado pelos antigos moradores.

Finalmente os tesouros de Pipa foram encontrados, foram desenterrados do anonimato e vendidos aos quatro cantos do mundo. Ao contrário do que pensavam seus antigos moradores, eles não se encontravam em botijas, escondidos em minas, mas sim à vista de todos. Entretanto, foi aos olhos dos forasteiros que eles se revelaram, informa Seu Madola: "Aqui ninguém sabe... nascemos e nos criemos aqui, mas ninguém sabia a boniteza daqui, porque aqui tudo era cheio de coqueiro, de mangueira, de tudo. Nós achava feio, já eles hoje sente porque tá tudo descoberto. [Construído?] É!”

E, a exemplo de outras localidades, os "saqueadores", representados pelos hoteleiros, munidos de um arsenal discursivo de teor desenvolvimentista, não tardaram em aparecer, cobiçando a pilhagem dessas preciosidades. Mas os seus legítimos proprietários, por sua vez, demonstrando a mesma ousadia e astúcia de outrora, não titubearam em tomar parte na divisão dessa fortuna. A metáfora é válida, pois o turismo chegou de surpresa, sem pedir licença, e impulsionou, sem pestanejar, a transformação da feiçáo do distrito. A maior parte das pessoas do local, em busca de uma melhor qualidade de vida, náo hesitava em ceder à especulação imobiliária e em se desfazer de suas propriedades.

Só os terrenos que era aqui perto da... aqui na Pipa mermo, pertinho, que a gente mora hoje em dia por aqui, eram esses terreno mesmo que tinham dono, num sabe? Esses terrenos mais pra lá adiante, onde esse povo tâo circulando hoje em dia, esses terreno o povo plantava, mas não era de ninguém, plantava, fazia um roçado...

Eles faziam uma queimada esse ano aqui nes- se canto, quando era no ano que entra já não plantava mais ali, já soltava aquele mato, já ia plantar noutro mato. Todo mundo trabalhava aí, agora quando chegou, começou a chegar turista e começou a comprar terreno, aí o povo se apossou tudinho, né? Cada um que quisesse o seu pedaço (D. Domitila).

Com a metamorfose do vilarejo em paraíso turístico, deu-se um processo de ocupação desordenada, pois após vender suas propriedades, os moradores de Pipa apossavam-se de outros espaços, cada vez mais em direçáo à área antes destinada às roças. Estes mesmos moradores, que viviam da pesca e da agricultura, em sua maioria, abandonaram suas atividades tradicionais e tornaram-se, a partir da invasão turística, camareiras, garçons, porteiros, recepcionistas, auxiliares de serviços gerais, motoristas, seguranças e caseiros dos empreendimentos dessa atividade globalizada. A dimensão mercadológica passou a governar as relaçóes sociais (Woortmann, 2007).

El turismo es parte de un gran movimiento de capital. Veraneantes y turistas, forman parte del proceso global de integración a un nuevo orden económico. [...] los turistas cambiaron a las personas del lugar. Buscando reencontrar el paraíso perdido en sus ciudades, corren el riesgo de construir el infierno para los 'auténticos' del lugar, repitiendo lo que ya ocurrió en otras localidades 'paradisíacas'. Por más 'alternativos' que se piensen, son parte del proceso que alteró el movimiento y la organización del espacio/ambiente (Op. cit., p. 481).

A atividade do turismo mudou, assim, não só a paisagem local, mas também as relaçóes de trabalho. Antes cada indivíduo era proprietário de sua terra e dono de seus instrumentos de produção, organizados como trabalhadores autônomos com vistas à subsistência, mas que 
agora, inseridos numa lógica capitalista, passaram a vender sua força de trabalho, cada vez mais especializada, conformando uma complexa divisão social do trabalho, aos proprietários dos equipamentos turísticos.

Em oposição, porém, à consideração feita por Woortmann (2007), a chegada do turismo, a apropriação das terras cultiváveis por hotéis e outros meios de hospedagem, além da ampliaçáo da oferta de trabalho, através da disponibilização de (sub)empregos por esses mesmos equipamentos, não alteraram apenas a condição social da mulher, o que para a autora desembocara em uma maior subordinação ao homem. Apesar de o mar (visto como domínio masculino) realmente não ter sido loteado tal qual grande parte das terras ("domínio" feminino) do distrito, a "indústria” do turismo tornou a atividade tradicional da pesca não mais atraente à maioria dos homens do local, principalmente os mais jovens. Poucos se dispóem a tirar seu sustento de uma atividade táo arrisca$\mathrm{da}^{14}$, preferindo trabalhar como recepcionistas ou garçons em terra firme. Portanto, o turismo separou mulheres e homens de seus meios de produção e inseriu-os na lógica do mercado, reconfigurando a ambos. Alguns autóctones, no entanto, conseguiram desenvolver um negócio próprio, mas poucos prosperaram.

Essa conjuntura fez, então, emergir em Pipa uma visível divisão de classes. Não que antes não existissem relaçóes de mercado, mas certamente elas ocupavam um lugar de menor destaque na sociedade. Assim, é somente a partir da chegada do turismo que o trabalho, a terra e os corpos assumem características de mercadoria.

A administração pública do município de Tibau do Sul, à qual Pipa está atrelada, deixou, por muito tempo, que a reordenação física e social provocada pelo turismo atuasse de forma livre e descontrolada, acreditando talvez na autogestão dessa atividade, seguindo as orien- tações neoliberais do livre-comércio ${ }^{15}$. Como resultado, grande parte de suas matas foram devastadas, dando lugar a pousadas, restaurantes, hotéis, lojas e resorts. Algumas espécies da Mata Atlântica local entraram em processo de extinção, como a Guabiraba ${ }^{16}$. Ademais, inúmeros desses hotéis encontram-se sobre falésias que, sem a proteção da cobertura vegetal, não resistem à força das ondas e findam por ceder mais rapidamente.

Si el espacio es un ambiente, un ecosistema, él no es apenas un ambiente natural, dado, más un ambiente cognitivamente aprendido y culturalmente construído. Como ambiente construído, es un espacio 'significado', cuyo uso social le atribuye un sentido. La noción de ambiente incluye, entonces, las relaciones sociales y la cultura que hacen de la "población" de ese ecosistema una sociedad. Si la historia es dada por la desarticulación del ambiente construído, ella es también el proceso de atribución de nuevos significados al espacio, de nuevos usos sociales, y del desplazamiento social de los agentes tradicionales. El cambio ambiental significa la alteración de las relaciones con el espacio, de los hombres entre sí, y de las mujeres con los hombres en función de ese espacio $(\mathrm{Op}$ cit., p. 481).

A mudança cultural acelerada, por isso mais visível, pela chegada do turismo em Pipa e a interpretação de Woortmann sobre o espaço, ordenado culturalmente, como significante e (res) significado, ressoam a ideia de Sahlins (2003) quanto à simultânea volatilidade e reprodutibilidade da estrutura, que se manifesta nas açóes dos agentes envolvidos no contexto. A atividade turística - elemento histórico, por isso contingente e arbitrário - transformou a conformação espacial da praia, a relação dos moradores com o espaço e entre si mesmos. A um só tempo, os turistas foram envolvidos pelas categoriais 
culturais locais (o forasteiro foi responsável pelo povoamento e surgimento do local, segundo as narrativas coletadas) e inseridos no seu ecossistema social. Dessa forma, a comunidade local investe crescentemente nessa atividade visando produzir "safras" cada vez maiores e mais rentáveis de visitantes, demonstrando que, mesmo tendo cambiado os significados do lugar e do cotidiano, esses "intrusos" são bem-vindos, pois são necessários para a reprodução da estrutura da conjuntura (Sahlins, 2003).

O ciclo do turismo sufocou quase totalmente os demais setores produtivos locais, impondo seu ritmo e suas demandas. Esse processo foi intensificado com a chegada dos grupos de turistas organizados pelas agências de viagem, a partir da segunda metade da década de 1990, que colocaram a Praia da Pipa dentro do circuito mundial do turismo. Dessa forma, a população local foi levada a se adaptar aos efeitos dessa atividade e reelaborar as bases de sua sociabilidade.

Apesar de alguns problemas terem surgido junto com o turismo, como o aumento do consumo de álcool e do tráfico de drogas "pesadas", como o crack, crescimento dos índices de violência (principalmente relacionados a assalto $^{17}$ ), desconfiguraçáo da paisagem local, desmatamento e degradação ambiental, segregação social, poluição sonora e visual, transformação contínua da arquitetura, desvalorização das atividades de produção e das manifestaçóes culturais tradicionais, os antigos moradores entrevistados encaram a chegada da atividade turística como positiva, uma cara aliada da Praia da Pipa, tendo em vista as benesses que a acompanharam, as quais se sobressaem em suas falas frente aos pontos negativos.

Ômi, pela umas coisas, pel'umas partes foi bom viu. [Pelo quê?] Pela parte de que hoje o pessoal vive melhor, num sabe? Com mais dinheiro. $\mathrm{O}$ pessoal, hoje da Pipa, ninguém sabe mais quem é pobre, tá certo de que todo mundo é pobre, ninguém é rico, mas à vista do que viviam, que o pessoal era uma casinha de taipa, às vezes tinha uns que num botava nem um barro no piso da casa, outros tinha uma casa arrochada de palha. E desse tempo pra cá tudo melhorou. Por isso que eu digo, melhorou nessa situação, agora sobre o negoço do povo ficare desobediente, filho não querendo mais obedecer a pai, essas coisa, esse negoço de corrupção, isso aí piorou, num sabe? Essas coisa piorou, mas no bem-estar do povo, eu acho que melhorou muito, melhorou muito (D. Domitila).

Na parte de ganhar dinheiro foi a melhor coisa que existiu, né? Trouxe desenvolvimento demais até, né? É trabalho pra todo mundo, né? [E a parte ruim?] E na parte ruim, de tranquilidade, né? Pra quem é nativo ficou ruim... Mas pra ganhar dinheiro foi uma das melhores coisas... Porque antigamente aqui se morria de fome, saúde era precária, tinha nada, rapaz, nem em Goianinha, viu? (D. Palmira).

Aqui, o [problema] que é maior é a tranquilidade, tranquilidade foi o que... [piorou]. Mas em outras coisas, graças a Deus, [o turismo] trouxe e tá trazendo muitas coisas. [Então, o senhor acha que o turismo foi bom para Pipa?] Foi bom, foi bom. As terras da Pipa, que tem vendida, se for construir é uma grande cidade (Seu Madola).

A aceitaçáo da atividade turística como algo positivo deu-se, entre outras coisas, em consequência do incremento da renda (o enriquecimento está muito atrelado à ideia liberal de "vencer na vida" e fazer-se a si mesmo) e da diversificação das atividades laborais, que permitiram saciar os desejos por individualização e por distinções identitárias (remontando à e procedendo da singularidade de seu mito de origem $^{18}$ ), que foram, por muito tempo, acordadamente, refreados em prol da estabilidade 
e coesão da comunidade, mas que também transpassam e marcam a maioria das sociedades da contemporaneidade.

A imediatez desses benefícios ofusca, porém, grande parte das desordens e problemas, principalmente sociais e ambientais, advindos com o turismo, frutos do rompimento que essa interaçáo com elementos externos provocou na tessitura social, o que fez com que problemas sociais fossem vistos como falências individuais, passando a vigorar a máxima do "cada um por si e Deus por todos". No entanto, o relato desses moradores mostra que eles se negam a construir um passado idealizado positivamente, ao contrário do que parece acontecer com os integrantes das comunidades investigadas por Woortmann (2007). Para os antigos moradores da Pipa, a lembrança das dificuldades e limitaçóes do passado faz com que eles se recusem a crer que o antes era melhor que o agora.

A unidade de outrora, baseada na similitude de crenças, sentimentos e valores morais, foi se rarefazendo. $\mathrm{O}$ individualismo e a divisão social do trabalho deslocaram a configuração societal para uma mais nítida diferenciação entre seus membros. Os agentes, cada vez mais atomizados, ao interagir com os turistas, deram início a um processo de hibridização de antigos valores morais, baseados nos dogmas religiosos, com representaçóes sociais de todas as partes do país e do mundo.

O contato intenso e constante da comunidade com os turistas transformou rapidamente uma série de fatores, que extrapolam as questôes relativas à economia, tirando a tranquilidade que marcava a antiga vila. Costumes, modos, valores e comportamentos - "sobre o negoço do povo ficare desobediente, filho não querendo mais obedecer a pai, essas coisa, esse negoço de corrupção, isso aí piorou, num sabe?" -, juntamente com os espaços de socialização, foram alterados. A mudança atingiu todas as esferas da sociedade pipense, desta- cando-se, para os fins do presente trabalho, os itinerários dos relacionamentos afetivo-sexuais, onde as parcerias entre autóctones e forasteiros/as, a exemplo da relatada por D. Palmira entre Abacate e Marleide, tornaram-se, com o tempo, comuns.

\section{Destino Pipa}

Hoje vou a Pipa. Só de pensar já me sinto bem. A viagem é rápida. Menos de duas horas. Saindo da região metropolitana do Natal, começam a se formar extensos canaviais, que tentam esconder o quanto desmataram a área ocupada com uma ínfima franja de Mata Atlântica margeando a estrada. A estrada está horrível de se trafegar. As obras federais de duplicação da BR-101 exigem desvios, paradas e provocam um pequeno engarrafamento. Mudo de ideia e começo a achar que desta vez a viagem não será tão rápida. Mas já saímos de Natal, passamos por Parnamirim e... "Que cidade é essa? É São José do Mipibu?” "É!", diz meu pai. "São José do Mipibu." - repete meu tio, lendo o nome da cidade que está estampado no jardim do ponto rodoviário local. É quase uma obrigação pararmos aqui, seja de ônibus ou de carro. "Aqui tem um São João bom da bexiga, visse?!" - completa meu tio. Ao falar isso me veio à cabeça a imagem de um professor meu de português, da época do secundário, natural deste município, que sempre com a proximidade das festas juninas fazia propaganda de São José como sendo o melhor São João do mundo.

Bem, comemos umas besteiras de rodoviária, que deixou meu estômago táo bagunçado quanto o interior dos quiosques onde eram vendidas. Seguimos. Os canaviais vão tomando conta da paisagem. É um verde bonito, meio prata, meio água. As folhas das canas bailam com o vento e a Usina Estivas se ergue no meio da plantação, cinza, cuspindo fumaça, fruto das caldeiras que preparam o melaço. Pouco à frente já avistamos 
Goianinha. Esse é o município que dá acesso à praia de Pipa. Daqui, além dos ônibus vindos de Natal, partem também muitas vans com destino final naquela praia. Goianinha vive quase só do comércio e da agricultura canavieira. Seu centro é pequeno. Rapidamente o cortamos e entramos na pista. São muitos os distritos pelos quais temos que passar até chegarmos ao nosso destino. Não sei pra que existem tantos, já que são todos muito parecidos e muito próximos. O único que consigo distinguir é Piau, porque fica próximo a uma curva e bem perto da sede de Tibau do Sul. Aliás, conforme vamos nos aproximando de Tibau, à nossa esquerda começamos a vislumbrar a Lagoa Guaraíras. É uma coisa incrível, ela se une ao mar bem na sede do município, o pôr-do-sol é esplendoroso, um espetáculo. Pena é que cada vez mais os mangues daqui estáo dando lugar a fazendas de carcinicultura. Na entrada de Tibau amontoam-se uma série de resorts e hotéis de luxo, todos afirmando ter a melhor paisagem do paraíso. Engraçado que apesar de tanto luxo e de tantos empreendimentos, a população daqui continua pobre. Gente humilde, com casas pequenas, na maioria, antigos pescadores e rendeiras que servem apenas para trabalhar nas funçóes mais serviçais desses imensos meios de hospedagem. A placa anuncia Pipa a menos de sete quilômetros. Quando deixamos o centro de Tibau do Sul, adentramos na parte final da viagem e sobre a pista que invadiu a duna, vemos os contornos da cidade lá em baixo. Para quem vai pela primeira vez, Pipa é um choque. As falésias do lado esquerdo formam mirantes naturais; ao lado direito estão as dunas semivegetadas. Vemos a praia da Ponta do Madeiro, o verde que desce por suas barreiras e as águas calmas que alisam a areia. Mais adiante tem uma reserva florestal, o Santuário Ecológico. Chego a Pipa, bastante animado, mas é óbvio, estamos às vésperas do reveillon e, finalmente, vou rever minha companheira, depois de estendidos 15 dias.
Vim dirigindo o carro do meu tio até aqui e, ao chegar à rua principal do distrito, vejo que não fui o único a fazer a escolha por Pipa para virar o ano. Na verdade, Pipa é um dos mais badalados reveillons do Rio Grande do Norte. A prefeitura espera 30 mil pessoas, apesar de nesse momento, pelo fluxo de carros e de gente na rua, parecer bem mais. Logo na entrada estava formado um engarrafamento, motivado pela já grande quantidade de visitantes e também devido às suas ruas estreitas. Sempre que venho aqui me deparo com novas construçóes advindas da especulação imobiliária, resultado da atividade turística. Então, Pipa sempre está de cara nova, "repaginada". Aqui parece uma Torre de Babel devido à diversidade de origem das pessoas. Línguas, sotaques e regionalismos linguísticos se embaralham lembrando uma espécie de esperanto. A cidade cheira a protetor solar (Notas de Diário de Campo - 29/12/2007).

A Praia da Pipa hoje em dia é uma área cosmopolita, apesar de ainda manter a atmosfera de uma vila de pescadores ${ }^{19}$. Muitos de seus atuais moradores são oriundos de diversas partes do Brasil e dos mais diferentes lugares do mundo. Esse cosmopolitismo torna-se mais evidente nos meses de verão, que comporta a chamada alta-estação do turismo, quando mochileiros $^{20}$ e turistas institucionalizados ${ }^{21}$ vindos de São Paulo, Recife, João Pessoa, Brasília, Itália, França, Portugal, Espanha, Canadá, Israel, Japão, Argentina, Uruguai, Estados Unidos, Holanda, Inglaterra, Suécia, Noruega se misturam à população local, formando um grosso "caldo cultural".

Numa pequena localidade com um intenso fluxo turístico é esperado que, desse encontro, ocorra uma série de relaçóes entre população fixada e população flutuante. Essas interaçóes se dão em situações em que o morador é transformado em prestador de serviços e em outras em que ele é apenas o nativo daquele destino 
turístico. De tais trocas resulta um continuum de sentimentos, onde de um lado encontramos a repulsa e do outro o fascínio, e um elemento que constitui essa fascinação é o desejo, a atração sexual. Através da mútua exotização e erotização do Outro, inúmeras possibilidades de relações afetivo-sexuais são empreendidas.

Durante a pesquisa etnográfica conseguimos observar e coletar informaçóes sobre a dinâmica de um exemplar desses encontros afetivo-sexuais que se dáo em contextos de viagem. Ao contrário do que pensa o senso comum e do que corriqueiramente foi, e ainda é, divulgado na grande mídia e em algumas áreas da academia, eles náo obedecem a uma receita invariável, sempre composta pelos mesmos ingredientes. Mostram-se, cada vez com mais clareza, como uma imbricada rede de socialização extremamente heterogênea, pouco habituada a determinismos, e pôe "sob rasura", apropriando-se da noção de Stuart Hall (2007), o conceito que disserta sobre a mescla entre sexo e atividade turística, conhecida prosaicamente como "turismo sexual".

Em Pipa, alguns homens, a maioria nativos e locais ${ }^{22}$, empreendem uma série de relacionamentos afetivo-sexuais com mulheres estrangeiras que, geralmente, encontram-se em contexto de viagem. Elas, em sua grande parte, sáo oriundas da Argentina, Europa Ocidental e dos países escandinavos. Por sua configuração ser inversa à que geralmente vem sendo analisa$\mathrm{da}$, pois aqui é a mulher que se desloca e usufrui dos "serviços" sexuais de homens autóctones, o caso de Pipa nos dá base para questionar a generificação das atividades do "turismo sexual" e do mercado de sexo.

Ao contrário do que possa parecer, esse tipo de interaçáo traz elementos que o destacam do prosaico e inviabilizam interpretaçóes reducionistas, que o enxergariam precipitadamente como um lugar comum, um comportamento típico de pessoas jovens. Para entendê-lo é pre- ciso saber como esses relacionamentos se dão, o que leva esses parceiros a empreendê-los, o que os positiva e os torna preferíveis frente às demais possibilidades de relacionamentos. Mas isso é um objetivo que não poderá ser alcançado neste trabalho, que pretende apenas mostrar como as alteraçóes vindas juntas com o - mas não devido exclusivamente ao - turismo implicam também em alteraçóes ${ }^{23}$ na subjetividade dos atores em cena, a exemplo do que ocorre nas relaçôes e representaçóes de gênero, no desejo de diferenciaçáo social, nos significados atribuídos ao que é do outro, etc., a partir das narrativas desses/as antigos/as moradores/as.

Para isso, é necessário, antes, deixar claro dois fatos que atuaram no processo de turistificação da Praia da Pipa e que nos são bastante caros para a compreensão desse fenômeno. Primeiramente, temos que lembrar que o turismo em Pipa consolidou-se como um dinamizador e potencializador da economia local, "melhorando" as condiçôes de vida da população - "pra ganhar dinheiro foi uma das melhores coisas... Porque antigamente aqui se morria de fome, saúde era precária, tinha nada, rapaz, nem em Goianinha, viu?”. Do mesmo modo, quando adotada oficialmente pelos órgãos governamentais, esta atividade foi, de certa maneira, sacralizada e apontada como condição essencial para possibilitar o desenvolvimento local ${ }^{24}$, firmando-se como via prioritária na agenda de investimentos públicos. Entretanto, a canalização de investimentos públicos e privados para o turismo tornou a comunidade demasiado dependente, em termos econômicos e simbólicos, do vai e vem de visitantes.

É difícil não constatar nem perceber o quanto o turismo está presente no cotidiano de Pipa. Evidencia-se nas pousadas e hotéis, nos bares e restaurantes, nas lojas de souvenirs, nas casas de câmbio; porém, devido à dinâmica da própria atividade, cujo núcleo produtivo não se mantém fechado, mas sim se espraia por outros 
setores da economia, a priori não relacionados com ela, mostra-se também em padarias, lan houses, farmácias, quitandas, mercados, principalmente através dos preços elevados.

O turismo trouxe consigo uma espécie de verdade, semelhante àquela representada pelo capitão Cook e seus marujos aos polinésios-havaianos, a "verdade do estrangeiro", como diria Sahlins (2003), que foi tomada pela maior parte da população da Praia da Pipa também como sua, estimulada pelas decisóes das autoridades políticas locais (em analogia aos sacerdotes havaianos) que a endeusaram a ponto de as atividades econômicas que faziam parte dos costumes pipenses, como a pesca, serem, por muitos, abandonadas ${ }^{25}$, como afirma um morador: "A maioria [trabalha] com turismo. Hotel. Eu acho que a Pipa toda é turismo, né? [Tem pouca gente trabalhando com pesca, né?] Só os mais velhos, pouquíssima pessoa. É tanto que a pesca na Pipa já tá acabando. [Daqui a próxima geração...] Não vai ter mais pescador" (Nilson, 27, bugueiro e barman).

A figura do turista e suas práticas foram também "endeusadas", iniciando um processo que Mário Carlos Beni (1998) chama de "efeito demonstração". Em pouco tempo, a população local começou a desejar roupas, costumes e estilo de vida do turista ${ }^{26}$, assim como ele mesmo. Tal comportamento corresponde ao que Marcel Mauss (2003) chamou de "imitação prestigiosa”, a reprodução de algo social e/ou culturalmente valorizado, a cópia de um ethos, que confere status àquele que o incorpora.

O valor atribuído não só ao que é próprio do outro, mas ao outro em si, denuncia as açóes de apropriação e ressignificação simbólica elaboradas pela comunidade receptora, que radicaliza o discurso propagandeado pelos representantes públicos e porta-vozes da iniciativa privada em louvor ao turismo e à salvação financeira que ele proporcionaria, através do slogan "O turismo gera emprego e renda!"
Não só a imitação possibilita a aquisição de prestígio. A inserção nesses grupos de forasteiros/adventícios torna-se também positivada, pois demonstra intimidade e familiaridade com seus códigos e estabelece uma ruptura dentro do próprio seio do grupo social local, que se divide entre os que estão e aqueles que náo se encontram dentro desses novos circuitos de sociabilidade, bem como entre os que se relacionam com os turistas apenas via prestação de serviços e aqueles que o fazem a partir de outros esquemas interacionais. Dessa forma, um dos mecanismos alçados por alguns membros da referida comunidade receptora, para terem acesso a tais representaçóes simbolicamente valorizadas, é o envolvimento afetivo-sexual com esses/as turistas.

Ademais, faz-se míster observar, e este é o segundo ponto a destacar, que a Praia de Pipa surgiu no cenário do turismo como um destino alternativo, propício àqueles que buscavam fugir da agitação do turismo de massa. Dessa forma, frequentada no início por surfistas, hippies e mochileiros, a praia ganhava ares de contracultura e boêmia. A partir disso a vila de pescadores assumia um tom e uma aura de permissividade e liberalidade tanto sexual quanto no que diz respeito ao uso de psicoativos, principalmente da maconha.

Atualmente, pode-se dizer que Pipa classifica-se como um destino massificado, dado ao fluxo de viajantes que recebe e à infraestrutura turística que possui, composta por um amplo leque de opçôes de meios de hospedagem, entretenimento e por um complexo gastronômi$\mathrm{CO}^{27}$ influenciado pelas e especializado nas mais diversas e renomadas cozinhas internacionais. Embora isso não signifique dizer que a praia tenha perdido seu "charme rústico" - que, na verdade, não passa de um simulacro criado e recriado pela arquitetura paisagística presente na maioria dos prédios comerciais, na busca incessante de apresentarem-se como represen- 
i 90 | Tiago Cantalice da Silva Trindade

tantes de um estilo arquitetônico tradicional, em harmonia com a paisagem natural ${ }^{28}$ - e sua mística permissiva, que ainda se prestam como chamarizes, conservando antigos e atraindo novos frequentadores.

Diga-se de passagem, por se tratar de um destino de turismo de lazer (ou turismo sol e mar), a grande parte dos visitantes que ali aportam busca, acima de tudo, diversão. Sabendo que as sociedades de onde provém parte dos turistas de Pipa (Europa Ocidental e Sudeste brasileiro, como São Paulo) são regidas por uma lógica prometeica, marcada pela produção, ocupação, controle e resultados, nas quais as atividades hedonísticas não possuem muito espaço, os destinos turísticos funcionam como redutos que possibilitam a emergência de sua face dionisíaca $^{29}$ (Maffesoli, 2001). Pipa presta-se a esse serviço.

A representação de Pipa como paraíso de sexo e psicoativos ${ }^{30}$, apesar de não ser oficial, parece ter se disseminado informalmente por vários lugares e também se fixado no imaginário local, conforme a fala de um informante nos revela:

Meu irmão, é aquela coisa doido. Tipo... já fosse pro Recife Antigo? Então, tu vai ali pro Recife Antigo é todo mundo parado, pá, é a mesma coisa. Agora você vai aí de noite mermão. Você vê a cara da galera: é sexo, tá ligado? A galera só quer sexo, véio. [risos] Você fica doido, pô. É gringa que só a porra, tudo... Você se chega ela já dá ouvido pra tu, tá ligado? Tem outras que dependendo do seu papo ou da sua cara, mermão, aí elas te aceitam, tá ligado? Mas é isso, a galera quer se drogar, quer fazer sexo, coisa boa num quer fazer. Ficam tudo... Aí é atacar mermão! [risos] [E como é que tu define a noite da Pipa?] Noite da orgia. Curto e grosso (Gabriel, 24, escultor e professor de capoeira).

Esse relato faz ressoar a noção de sacred journey, de Nelson Graburn (1989), em que a viagem turística está inserida. Tomando como referência os países centrais, pode-se visualizar a vida como uma contínua alternância entre dois modos de existência, regidos por distintos padrôes morais: o tempo ordinário/profano e compulsório do trabalho e outras obrigaçóes, cerrados no espaço do lar, e o tempo não ordinário/sagrado, voluntário e prazeroso, cujo representante-mor é a viagem (Graburn, 1989).

Como esses períodos de sacralização da vida social são bastante curtos em comparação ao cotidiano profano, as pessoas tendem a vivenciá-los de forma intensa, em busca de "estados alterados". Daí justifica-se, de certa forma, o aumento no consumo de álcool e outras drogas, bem como a despreocupada emergência das pulsóes sexuais. As férias em terra estranha possibilitam o vivenciar da errância sexual (Maffesoli, 2001), livre do peso das prestaçóes sociais da community home. Tais comportamentos, ao contrário, possuem o respaldo moral dessas comunidades, posto que os valores do turismo moderno, além do status social, estão vinculados à diversão e às "experiências exóticas". O inusitado, o mágico, o efêmero, a fugacidade que marcam esse momento extraordinário/sagrado faz com que aqueles que o vivenciam o percebam e interpretem como mais real que a "vida real", pois sua única obrigação é com a satisfação pessoal (Graburn, 1989).

Para a comunidade receptora, desvinculada das atividades tradicionais, o que interessa é como ela pode se beneficiar desse comportamento "desregrado" dos turistas. Se eles estáo dispostos a gastar, é preciso saber aproveitar e disponibilizar serviços que atendam a suas expectativas, que sejam condizentes com a fama da hospitalidade brasileira e que lhes convençam de que estão realmente no "paraíso". Se desejarem vivenciar, comprovar e experimentar as diferenças, atualizando as estruturas hierárquicas de poder mundialmente disseminadas (Scott, 2007), a população tratará de reforçá- 
-las conscientemente para também tirar proveito desses eixos produtores de desigualdade ${ }^{31}$.

Frente a essa nova conjuntura, seduzir, galantear e envolver-se afetivo-sexualmente com mulheres estrangeiras é para alguns homens nativos/locais uma forma de tomar parte nos louros e nos lucros gerados pelo turismo, pois esses relacionamentos surgem como vias de acesso facilitado a bens e símbolos socialmente valorizados.

Entretanto, essas novas formas de relacionamentos afetivos, particularmente as parcerias binacionais, causam opiniôes diversas e divergentes entre os moradores antigos. D. Palmira e Seu Madola assumem um discurso um tanto moralista frente à permissividade e à fugacidade desses relacionamentos:

Ah, hoje em dia é só um tal de ficar. [gargalhada] [As pessoas costumam namorar com turistas?] Hoje em dia o que vale é o turismo, é o turista, é o gringo, que o povo explora. [E o que é que a senhora acha?] Eu pelo menos, tem umas gringa que me aparece aqui que eu vou te dizer, viu. [risos] 'Uns malacas [malandros] daqueles', como dizia Joca. Vive aqui com a gente. [Mas tem aumentado esse tipo de relacionamento? O pessoal tem casado com turista, com estrangeiro?] Olhe, Tiago, tem pessoas que já casaram, já foram, aí, tẫo morando fora, isso aconteceu muito. [Mas isso tudo a família aprova? As famílias daqui como é que vêem isso?] É, porque elas ajudam muito, acham que porque casou com gringo é tudo, né? Então, vão embora e... [O que você acha das turistas pagarem coisas para os homens daqui?] Ah, isso aí eu acho o fim da picada, como diz a história, porque eu acho que cada um tem que ter... como se diz? Independência, porque no momento que um vai procurar uma gringa só porque tem dinheiro, é porque náo tem coragem de trabalhar, né isso? [...] Aí eu acho assim, que as pessoas se quer, tudo bem. Quer conhecer, quer ir embora, se gostou, vá. Mas vá com a sua independência, porque se for depender dos outros, aí em lugar nenhum não dá certo, né? Em lugar nenhum isso não existe. [Essa foi uma mudança trazida pelo turismo?] Eu acho que foi, porque vê essa história, porque... e principalmente aqui em Pipa, né? Porque antes os homens daqui viviam o quê? Trabalhando pra sustentarem as mulheres, né? E hoje em dia não. Eles fazem o contrário, né? Principalmente o povo mais jovem, já vê o contrário, as mulheres que, principalmente gringa, tem que sustentar eles, né? Aí, isso não existe, de maneira alguma (D. Palmira).

Os namoro? Mudaram. O negoço hoje tá solto no meio do mundo. É, de primeiro, o camarada namorar com uma moça é preciso fazer, ela tava lá acolá e de cá o cabra já tava batendo as pestana pra ela. Hoje não, só é chegar na casa dos pais mesmo, pegar ela na mão e sair pelo meio do mundo. Hoje a liberdade é maior. [ $\mathrm{E}$ hoje em dia tem um pessoal que namora com turista?] Tem um bocado deles, tanto os de fora também. Esses turista quando vêm, parece que vêm assim mesmo de paquerar. [Com as pessoas daqui?] Com as daqui e de fora que vem por aqui e de todo canto. Eles chegam aqui, cada homáo que é dessa altura, com umas coisinha desse tamanho, anda debaixo do sovaco deles, morenazinha, essas coisa. E aqui já tem, já foi donas que... Uns leva elas só pra fazer elas sofrer lá, mas tem outros que... Tem uns que casou e vive bem. [... O que você acha?] Com turista? Rapaz, esses namoro dos turista com brasileiro, eles parecem que quando vêm, já vêm na certa, é. Eles só tão esperando...elas acham que todo turista é rico, todo turista é rico. [... Os homens daqui também? As turistas sustentam eles?] É, eu acho, sabe porque é... Hoje muitos anda a procura dessa garapa [leia-se: de uma vida fácil], que elas vão, eles sabe que ela tem alguma coisa, ela pode ser feia, pode ser o que for, mas vai em cima pra modo do dinheiro. [O que o 
I92 Tiago Cantalice da Silva Trindade

senhor acha do homem ser bancado por mulher?] Eu acho que tudo no mundo, essas coisas assim, a mulher pode até um dia que sentir mal dele, pode até chagar e dizer: 'Tu sois assim, porque eu tenho, eu fico te sustentando, assim, assim, né?' E quando o homem toma conta de sua responsabilidade, por família, por mulher, por tudo, ele tá sabendo que tem toda garantia, porque a responsabilidade é dele. Ele num pode levar uma piada duma mulher nenhuma, porque a responsabilidade é dele. Mas esse povo que pegar uma mulher aqui, à procura do dinheirinho que ela tem, tá sujeito a uma piada dela, essas coisas, né? [...] Hoje aí, a maior parte é na boa, viu. Muitos aí, tem uns que a mulher é empregada e eles nem ligam. Num quer trabalhar. Outros, como se diz, a mulher quando diz qualquer coisa pra eles, dizer que eles quere ficar vivendo às custas dela, aí quer se revoltar, né? (Seu Madola).

Como podemos visualizar, ambos os relatos apontam para uma desaprovação desses câmbios afetivo-sexuais binacionais. Tanto D. Palmira quanto Seu Madola começam falando da falta de compromisso dos relacionamentos atuais. Logo em seguida, quando questionados sobre os relacionamentos entre brasileiros(as) e estrangeiros(as), eles expressam certa crítica a essas unióes, amparando-se em discursos que se prendem à ideia de que elas sempre são motivadas, por parte de um dos parceiros, por expectativas de exploração, de benefício próprio - "Hoje em dia o que vale é o turismo, é o turista, é o gringo, que o povo explora”. Por outro lado, Seu Madola acha que os turistas já vêm para Pipa com a intenção de namorar - " [...] parece que vêm assim mesmo de paquerar". Porém, esses dois interlocutores concordam que muitas pessoas, em Pipa, se relacionam com os (as) visitantes, pois se criou localmente uma representação do(a) turista estrangeiro(a) como sendo um indivíduo de posses, bem-su- cedido, rico. Isso, de acordo com eles, é o que faz as famílias apoiarem esses relacionamentos.

$\mathrm{O}$ tom da conversa muda quando começamos a enfatizar as parcerias entre homens nativos/locais e turistas estrangeiras. Montando uma comparação com as apreciaçóes que eles fizeram, a priori, os juízos de valor e os discursos moralizantes, a partir dessas novas questóes, surgem com bem mais veemência. As condenações são explícitas quando trazemos pontos relativos à evocaçáo por parte das turistas do papel de provedoras no âmbito da relaçáo "Ah, isso aí eu acho o fim da picada, como diz a história [...]"; "[...] hoje muitos anda a procura dessa garapa, que elas vão, eles sabe que ela tem alguma coisa, ela pode ser feia, pode ser o que for, mas vai em cima pra modo do dinheiro", Do mesmo modo, recorrem aos papéis de gênero tradicionalmente postos para embasar sua desaprovaçáo, noutras palavras, na visáo de ambos, cabe apenas ao homem assumir as funçóes de provedor.

Em oposição a essas falas, D. Domitila, a mais velha desses antigos moradores, apresenta uma interpretação menos moralista, sendo que, para ela, é normal que quem tenha mais recursos termine por pagar pelo acesso a bens e serviços, além de se tratar de uma necessária distribuição de renda - "Tem que partir o pão, né?":

[Agora também tem homem que namora com gringas?] É. Tem. Tanto elas casam como eles casam também. Tanto é aqui como em Tibau, Cabeceira, Goianinha, tudo tem esse povo que casa. [Mas essas gringas, que se casam com nativos, elas dão dinheiro pra eles e pras famílias deles também ou não?] Sim, o contrário. Ajuda, porque já tem diversas gringas com rapaz da Pipa, diversos. [... O que você acha de mulheres pagarem coisas para os homens daqui?] Eu num acho problema não. Isso é bom mesmo. Pois é. Tem que partir o pão, né? 
O interesse extrassexual, visto com aversão por uns e com naturalidade por outros, deveras caracteriza esses relacionamentos binacionais contemporâneos, que se colocam em oposição ao antigo modelo vivenciado por esses interlocutores, em que os papéis de gênero eram bem demarcados, o intercurso sexual deveria ser precedido pela benção do "sagrado matrimônio" e os relacionamentos eram extremamente controlados. Vale ressaltar, no entanto, que os relacionamentos afetivo-sexuais que ocorrem atualmente em Pipa envolvendo autóctones e turistas não se resumem aos estabelecidos entre homens nativos/locais e turistas estrangeiras. Conforme as falas e durante a permanência no campo, foram observadas outras várias conformaçôes, que, assim como aquelas, estavam inseridas ou não em alguma variação do sexo mercantil: como entre esses mesmos homens e brasileiras de outros estados; mulheres nativas/ locais e estrangeiros/brasileiros de outras regióes; e pessoas do mesmo sexo. Havia ainda a formação de parelhas entre os próprios turistas e, logicamente, entre os nativos/locais. Vê-se que as possibilidades de arranjos afetivo-sexuais se ampliaram, assim como as razóes motivadoras para seu empreendimento - não estando mais presas à representação do "amor romântico" (Giddens, 1993) -, o que aos olhos de alguns é o "fim da picada", num claro exemplo de choque de geraçôes.

\section{Conclusão}

Percebe-se, então, que o realce dado às consequências negativas do advento da atividade turística, principalmente quando os destinos se tratam de pequenas localidades (os famosos "paraísos", que se multiplicam a cada ano), revela uma subestimação das açóes de apropriação e ressignificação da população autóctone em referência ao turismo e seus corolários, estando diametralmente em oposição aos pode- res atribuídos aos viajantes, devido ao acúmulo de capital financeiro e cultural. Dessa forma, tais estudos, principalmente quando se debruçam sobre as alteraçóes nos modos de vida da populaçáo local e, ainda com mais ênfase, quando se dedicam à análise da relação entre práticas sexuais e turismo, parecem subsumir a açáo ativa e criativa das comunidades, delegando-lhes certa atmosfera de inocência, pureza e passividade rompidas pela chegada do turismo e a invasão de seus adeptos. Mas o que se deve observar, para além dessa visão saudosista, são os mecanismos de reformulações simbólicas de teor combinatório encontrados por essas comunidades, em que são agenciadas e articuladas novas formas de relações sociais, que finda por marcar o processo de turistificaçáo como um processo extremamente tensionado, onde o discurso vitimário não encontra base, além da demagogia de uma harmonia e pureza originais, e como uma tentativa de instaurar um pânico moral, que, na realidade, não possui respaldo nem mesmo entre os membros da comunidade tida como atingida pelos males dessa atividade (pós-)moderna.

\section{Routine before Paradise: Narratives on the History of a Potiguar Tourism Destination}

abstract This article intends to accomplish a brief analysis of the changes in the daily life of the community of the beach of Pipa-RN, which were directly caused by the advent of tourism - part of the local landscape. Based on data collected in ethnographic research, in which the older residents of the district played an essential role in the construction and record of their oral history, we have sought to question the ordinary representation tourism destinations as pure, authentic, and naive, being this harmony threatened by the intense flow of outsiders. Therefore, this work tries to evidence how tourism can change the local networks of sociability 
while the host community creates mechanisms of symbolic reformulation to face these changes., In other words, even when they are induced by external factors, they are conducted in a native way, what becomes clear through the observation of changes in gender relations.

keywords Oral History. Tourism. Relations and Gender Representations. Cultural Exchanges. Agency.

\section{Notas}

1. A maior parte desses vôos internacionais é fretada, os chamados vôos charters.

2. Mais informação podem ser encontradas no site da Secretaria Estadual de Turismo do RN: http://www. brasil-natal.com.br/setur estatisticas.

3. Além dos países acima citados, Pipa também é visitada por turistas vindos da Suécia, de Israel e alguns países que compunham a antiga Iugoslávia.

4. Acessar: http://www.ibge.gov.br/home/estatistica/populacao/contagem 2007.

5. O site http://www.tibaudosul.com.br/conteudo/informativo/conheca.html informa que a população de Tibau do Sul é de 7.757 habitantes. Já a enciclopédia livre Wikipedia informa que são 11.347.

6. A ocupação holandesa no Rio Grande do Norte se deu entre 1634 e 1654, iniciando-se com a ocupação da fortaleza dos Reis Magos e se estendendo por quase todo o litoral sul do estado, com destaque para o município de Canguaretama (vizinho ao município de Tibau do Sul, onde fica localizada a Praia da Pipa).

7. Francisco Fernandes Marinho (2007), historiador nascido em Pipa, afirma que o local ainda se chamou Itacoatiara, mas nenhum dos interlocutores confirmou essa versão.

8. Tal discurso se assemelha bastante ao que alguns grupos de descendentes de imigrantes acionam, ao redor de todo o Brasil.

9. Curral é uma técnica tradicional de pesca, em que é criado um cercado, por onde os peixes entram na maré alta, mas ficam presos na maré baixa.

10. O Coco de Zambê é uma variaçáo da dança do Coco disseminada por grande parte do Nordeste brasileiro, como o Coco de Roda e o Coco de Ganzá. Na regiáo de Tibau do Sul, ele é o maior representante da musicalidade e das danças populares locais. Em
2007 foi lançado um livro chamado "Fotografias do Coco de Zambê", de autoria de Candinha Bezerra, e um CD, "Zambê Pernambuquinho", ambos pelo selo Nação Potiguar. De acordo com Bezerra, o grupo de Pernambuquinho, distrito de Tibau do Sul, liderado pelo Mestre Geraldo, é o mais antigo do Rio Grande do Norte. Ver: http://www.nominuto.com/vida/ cultura/nação-potiguar-lanca-relato-sobre-coco-de-zambe/8854/.

11. Talvez seja consequência de aqui não privilegiarmos o ponto de vista de homens ou mulheres, mas sim de estarmos comprometidos com a busca do ponto de vista nativo, como ensinou Malinowski (1978), e de destacarmos o teor relacional de todos os âmbitos da vida social.

12. O drama era uma espécie de encenação, poesias cantadas em forma de teatro. Esse teatro cantado só é encenado por mulheres e, de acordo com a tradição portuguesa, só virgens poderiam atuar.

13. Categoria êmica, que já vem sendo adotada por vários autores que se dedicam ao estudo do turismo internacional e suas dinâmicas junto às comunidades receptoras, dentre eles Adriana Piscitelli (2001) e Kamalla Kempadoo (2004). Blanchette (2001) define gringos histórica e sociologicamente como aquilo que não é brasileiro e tem poucas chances de um dia ser, mas que está entre nós. Esse termo, utilizado pela população pipense para identificar, com maior frequência, estrangeiros vindos da Europa e da América do Norte, bem como a expressão nativo(a), usada como uma autorreferência entre aqueles que nasceram na Praia, serão tomados neste trabalho, a exemplo das autoras acima, como categorias analíticas. Todavia, para recordar sua origem empírica, essas palavras surgirão destacadas em itálico.

14. A título de exemplo, durante a pesquisa etnográfica, o barco de um grupo de pescadores perdeu o leme e passou mais de dois dias à deriva, até a correnteza levá-lo para perto da costa, numa praia da regiāo metropolitana do Natal.

15. Arim do Bem diz que o turismo, nos destinos periféricos, "passou a ser desenvolvido de modo intuitivo, sem o respaldo de pesquisas científicas e sem a presença marcante dos profissionais qualificados, capazes de compreender a amplitude e a complexidade da atividade [...]" (Bem, 2005, p. 27).

16. Sua madeira foi intensamente utilizada na fabricação de mesas e cadeiras, ao mesmo tempo em que serviu de elemento decorativo de diversas construçōes, já que devido a sua estrutura peculiar dava a elas um charmoso ar de rusticidade. 
17. Ver reportagem da Tribuna do Norte Online: "Turista sueco é assassinado após assalto a pousada em Pipa”, publicada no dia 01/03/2009 por Ciro Marques em: http://tribunadonorte.com.br/noticias/102325. html.

18. A relativa facilidade que a populaçáo pipense tem em lidar com pessoas de outras regiōes e nacionalidades talvez se explique por sua origem também ser marcada pelo convívio entre brasileiros (posseiros) e estrangeiros (italianos), tomando por base os relatos acima.

19. Banducci Júnior (2001) diz que essas tensôes entre globalismo e localismo, entre o rústico e o sofisticado, entre o regional e o internacional marcam muitos destinos turísticos no Brasil, especificamente aqueles que atraem grandes levas de estrangeiros. Refletindo esse fenômeno na praia de Armação de Búzios - RJ, cujas semelhanças com Pipa são sensíveis, ele afirma: "A presença desses estrangeiros imprimiu na provinciana aldeia de pesca as marcas da metrópole, caracterizada pela sofisticação, pela diversidade cultural, pelo convívio ao mesmo tempo próximo e superficial, definido pelo caráter transitório das relaçóes pessoais. Se Búzios atraiu os moradores estrangeiros por representar oposição a suas origens metropolitanas, por ser a antimetrópole, ao acolher as diferenças, ao imprimir a marca das relações impessoais e transitórias, a cidade definiu seu traço cosmopolita” (Banducci Júnior, 2001, p. 41).

20. São aqueles viajantes que organizam e realizam suas viagens independentemente, estabelecendo, por conta própria, seus roteiros e o período de sua estada. Geralmente, interagem mais facilmente com as comunidades receptoras e utilizam equipamentos de hospedagem mais alternativos, como os campings e os albergues da juventude, mais acessíveis que os preços dos hotéis.

21. São os turistas que viajam a partir da mediação das agências de viagens, através de seus pacotes turísticos, tornando-se prisioneiros de seus roteiros, que definem previamente o que deve e o que náo interessa ser visto. Na maioria das vezes, fazem uso dos equipamentos de hospedagem e de restauração (alimentos e bebidas) mais pomposos.

22. Ambas são categorias êmicas. Segundo os próprios interlocutores, locais são os adventícios que vivem em Pipa há pelo menos cinco anos.

23. Vale frisar que as alteraçóes em questão podem acarretar o reforço e/ou relaxamento da estrutura.

24. O pesquisador Arim do Bem afirma que da perspectiva dos países receptores, em particular, no caso de vários destinos turísticos do Nordeste brasileiro, “o desenvolvimento do turismo está ligado à necessidade de dar início ou continuidade ao processo de modernização, considerando-se o turismo, portanto, um instrumento privilegiado para dinamizar a atividade econômica, às vezes, até superestimado como alternativa econômica" (Bem, 2005, p. 22).

25. Para mais informaçóes sobre contatos interculturais diaspóricos e teoria da mudança, ver Bhabha (1998) e Appadurai (1998). Para uma análise sobre as consequências dessas situaçóes de contato voltada às comunidades identificadas como "de pescadores", ver Woortmann (2007).

26. Sahlins informa que os chefes havaianos "se apropriaram de personagens da grandeza europeia ao mesmo tempo que imitavam o estilo adequado de vida luxuosa da Europa. [...] No início do século XIX, esse 'vestir-se' como identidades preeminentes estrangeiras tinha virado alta moda no Havaî” (2003: 176).

27. Um evento que reflete a variedade da culinária dos restaurantes da praia é o Festival Gastronômico de Pipa, que ocorre desde 2004, sempre no mês de outubro, e movimenta um grande fluxo de visitantes.

28. Não obstante, várias espécies da flora local entraram em processo de extinçáo devido ao uso de sua madeira como elemento decorativo desses empreendimentos que se vendem como ambientalmente responsáveis.

29. Ana Rosa Lehmann-Carpzov (1994) traz uma interpretação da viagem como uma experiência sagrada e costura uma analogia com os cultos dionisíacos.

30. Nos dias atuais, o consumo e a venda náo se restringem à maconha. Junto com a inserçáo de Pipa no circuito internacional do turismo, o local foi anexado à rota de outros psicoativos, como o crack, a cocaína (conhecida popularmente como pó ou bright), o ecstase (também chamado de bala) e o LSD (ácido lisérgico chamado vulgarmente de doce).

31. A interação, presente na maioria das viagens turísticas, entre turistas e população local, é mais um dos produtos oferecidos pela "indústria" do turismo. Em muitas ocasióes, a comunidade receptora integra a paisagem vendida pelo marketing turístico e, assim, durante a sua estada, o viajante deseja comprovar a existência daquelas personagens. Dessa forma, a "indústria" do turismo lança mão, como afirma Silveira, de um processo de "vitrinização", transformando "os nativos, seus modos de ser, de construir, habitar e morar em 'vitrines' para uma observação parecida com um zoológico social e cultural”

cadernos de campo, São Paulo, n. 19, p. 173-196, 2010 
i96 | Tiago Cantalice da Silva Trindade

(2007: 25). Como esse panorama implica uma invasão do cotidiano dos autóctones, esses tratam de construir bastidores, que permanecem anônimos frente a essa "autenticidade encenada” (Maccannell, 1973). Há, portanto, uma incorporação consciente e astuciosa do exotismo pela comunidade receptora, que, identificando os alvos do olhar do turista, manufatura o autêntico, tirando o maior proveito possível dessas situaçóes de contato.

\section{Referências bibliográficas}

APPADURAI, Ajurn. Disjunção e diferença na economia cultural global. In: FEATHERSTONE, Mike (Org.). Cultura Global. Rio de Janeiro: Editora Vozes, 1998.

BANDUCCI JÚNIOR, Álvaro. Turismo e Antropologia no Brasil: estudo preliminar. In: BARRETTO, Margarita; BANDUCCI JÚNIOR, Álvaro (Orgs.). Turismo e identidade local: uma visâo antropológica. Campinas: Papirus, 2001.

BEM, Arim Soares do. A Dialética do Turismo Sexual. Campinas: Papirus, 2005.

BENI, Mário Carlos. Análise estrutural do turismo. São Paulo: SENAC, 1998.

BHABHA, Homi K. O local da cultura. Belo Horizonte: UFMG, 1998.

BLANCHETTE, Thaddeus Gregory. Gringos. Dissertação (mestrado). Programa de Pós-Graduação em Antropologia Social, Universidade Federal do Rio de Janeiro, Rio de Janeiro, 2001.

GIDDENS, Anthony. A transformação da intimidade: sexualidade, amor \& erotismo nas sociedades modernas. São Paulo: Editora Unesp, 1993.

GRABURN, Nelson H. H. Tourism: a sacred journey. In: SMITH, Valene L. (Org.). Hosts and Guests: the
Anthropology of Tourism. Filadélfia: University of Pennsylvania Press, 1989.

HALL, Stuart. Quem precisa da identidade? In: SILVA, Tomaz Tadeu da (Org.). Identidade e diferença: a perspectiva dos estudos culturais. 7. ed. Petrópolis: Vozes, 2007. p. 103-133.

KEMPADOO, Kamala. Sexing the Caribbean: Gender, Race and Sexual Labor. Nova York: Routledge, 2004.

LEHMANN- CARPAZOV, Ana Rosa. Turismo e Identidade: Construção de identidades sociais no contexto de turismo sexual entre alemães e brasileiras na cidade de Recife. Dissertação (mestrado). Programa de Pós-Graduação em Antropologia, Universidade Federal de Pernambuco, Recife, 1994.

MAFFESOLI, Michel. Sobre o nomadismo: vagabundagens pós-modernas. Rio de Janeiro: Record, 2001.

MALINOWSKI, Bronislaw. Os argonautas do Pacifico Ocidental. Coleção Os Pensadores. São Paulo: Ed. Abril, 1978.

MARINHO, Francisco Fernandes. Literatura da Praia de Pipa. Natal: s/n, 2007.

MAUSS, Marcel. Sociologia e antropologia. São Paulo: Cosac\&Naify, 2003.

PISCITELLI, Adriana. Gringos nos Trópicos: gênero e nacionalidade no marco do turismo sexual em Fortaleza. In: CASTRO, Mary Garcia. (Org.). Migraçôes Internacionais, contribuiçôes para politicas. Brasília: Comissão Nacional de População e Desenvolvimento. v. 1, 2001, p. 589-613.

SAHLINS, Marshall. Ilhas de História. Rio de Janeiro: Jorge Zahar, 2003.

SCOTT, Russel Parry. Turismo, Poder e Comunidades Locais: fluxos, organização e significados entre Brasil, Europa e os Estados Unidos. 2007.

WOORTMANN, Ellen. Cambios de Tiempo y Espacio/ Cambios Sociales, bajo el Impacto de la Modernización. In: Revista Estudos Feministas. Santa Catarina: UFSC, v. 15, n. 2, p. 476-484, 2007.

\section{autor Tiago Cantalice da Silva Trindade Mestre em Antropologia / UFPE}

Recebido em 07/03/2010

Aceito para publicação em 20/09/2010 